\title{
THE RELATIONSHIP BETWEEN DISPOSITIONAL ENVY AND KNOWLEDGE SHARING
}

Fitnat Nazlı SAYĞAN YAĞIZ ${ }^{1}$

\author{
Received Date (Başvuru Tarihi): 03/02/2020
}

Accepted Date (Kabul Tarihi): 01/03/2020

Published Date (Yayın Tarihi): 25/03/2020

\begin{abstract}
According to the "Social Value Orientation" model, the value orientation of individuals is divided into two categories as prosocial and proself. Proselfs (individuals with proself value orientation) are reluctant to share their knowledge. Within the scope of this study, individuals with dispositional envy are described as proselfs. There are studies in the literature in which envy is considered as a feeling and associated with sharing knowledge. However, no study is found on the relationship between knowledge sharing and dispositional envy which is a personality trait. In this study, based on the "Social Value Orientation" model, the relationship between dispositional envy and knowledge sharing is investigated. Knowledge sharing is vital in the banking sector, where knowledge management technologies are used extensively. For this reason, this study was carried out on 175 bank employees in the banking sector. Quantitative research methods were used in the study. Findings show that dispositional envy is negatively related to knowledge sharing.
\end{abstract}

Keywords: Dispositional Envy, Knowledge Sharing, Social Value Orientation, Banking Sector

Jel Codes: M10, M12

\section{HASETLİK EĞIILIMI VE BİLGI PAYLAŞIMI İLIŞKISİ}

$\ddot{O Z Z}$

"Sosyal Değer Yönelimi" modeline göre, bireylerin değer yönelimi prososyal ve kendine yanlı olmak üzere iki kategoriye ayrllmaktadır. Kendine yanlılar (kendine yanlı değer yönelimli bireyler) bilgilerini paylaşmak konusunda isteksizdirler. Bu çalışma kapsaminda, hasetlik eğilimi olan bireyler kendilerine yanl olarak ele alınmaktadır. Yazında hasetliğin bir duygu olarak ele alındı̆̆ ve bilgi paylaşımı ile iliş̧kilendirildiği çalışmalar mevcuttur. Ancak bir kişilik özelliği olarak hasetlik eğiliminin bilgi paylaşımı ile ilişskisine dair bir çalışmaya rastlanmamıştır. Bu çalı̧̧mada, "Sosyal Değer Yönelimi” modelinden yola çıkılarak hasetlik eğilimi ile bilgi paylaşımı arasındaki ilişki incelenmektedir. Bilgi yönetimi teknolojilerinin yaygın olarak kullanıldığı bankacılık sektöründe bilgi paylaşımı hayati önem taşımaktadır. Bu nedenle bu çalışma bankacılık sektöründeki 175 banka çalışanı üzerinde yapılmıștır. Araştırmada nicel araştırma yöntemleri kullanılmıştır. Bulgular, hasetlik eğilimi ile bilgi paylaşımı arasında negatif bir ilişki olduğunu göstermişstir.

Anahtar Kelimeler: Hasetlik Eğilimi, Bilgi Paylaşımı, Sosyal Değer Yönelimi, Bankacılık Sektörü

Jel Kodlart: M10, M12

${ }^{1}$ Doct. Student, Marmara University, nazlisaygan@gmail.com

https://orcid.org/0000-0001-6780-8061 


\section{INTRODUCTION}

In this study, the relationship between dispositional envy and knowledge sharing is investigated. While in many studies, the relationship between the sense of envy and knowledge sharing is investigated, there is no study found searching the relationship between dispositional envy and knowledge sharing. Envy is an undesired and painful feeling that results from an upward social comparison in daily experiences (Smith et al. 1999). Dispositional envy is a personal trait which expresses individuals' tendencies to feel envy (Rentzsch and Gross, 2015b: p.530; Xiang et al. 2017; Smith et al., 1994). Personality trait is a term used to describe people with stable patterns of behavior, thoughts and emotions. Since behavior, emotions and thoughts repeat consistently, they turn into a personality trait (Leduc, Feldman and Bardi, 2015: p.3). Xiang et al. (2017) express dispositional envy as a personal trait which is the result of "chronic feelings of inferiority and ill will”. Within the scope of this study, dispositional envy which is a personality trait is searched rather than the sense of envy that individuals feel as a result of social comparison in their daily experiences.

"Social Value Orientation" model (Lange and Liebrand, 1991), which is frequently used in social psychology literature, suggests that individuals allocate the outputs based on their stable value orientations. Value orientations are categorized as prosocial and proself value orientations (Lange and Liebrand, 1991; Cremer and Lange, 2001; Galette et al. 2003: p.3; Manesi, Lange and Doesum, 2017). Individuals with prosocial orientation make the distribution of outputs considering both their own benefits and the benefits of others while individuals with proself orientation try to maximize their own benefits. Prosocials (individuals with prosocial orientation) show willingness to help people. On the other hand proselfs (individuals with proself orientation) try to increase their self-interest rather than helping people (Lange and Liebrand, 1991; Cremer and Lange, 2001; Manesi et al. 2017). Dispositional envy is a personal trait that causes individuals to maximize their own interests rather than benefiting other individuals. Individuals with high dispositional envy may feel inferior when their colleagues have higher qualities than themselves and therefore tend to increase their own interests rather than providing a common benefit (Rentzsch and Gross, 2015b: p.530; Smith et al. 1999). In Leder et al.'s (2019, p.38) research it is found that individuals with high dispositional envy often make decisions based on their personal interests when there is a conflict between self-interest and joint welfare. 
Dispositional envy as a personal trait consists of proself value orientations and individuals with dispositional envy are considered as proselfs (Leder et al. 2019). Several studies (Galetta et al., 2003: p.9; Marks et al. 2008: p.62- 63) indicate that proselfs are reluctant to share their knowledge. They act less in favor of their colleagues. In several studies (Marks, et al. 2008; Galetta et al. 2003), it has been determined that there is a negative relationship between proselfs and knowledge sharing. In this study individuals with dispositional envy are considered as proselfs and therefore this study was designed to investigate the relationship between dispositional envy and knowledge sharing based on "Social Value Orientation" model.

Since dispositional envy is a phenomenon related to human nature, it is possible to be confronted with it wherever human is. However, there is higher incidence of dispositional envy among employees in the sectors where interpersonal competition is intense. Dispositional envy can arise in the workplace due to the competition for scarce resources, lack of time or promotions (Gonzalez- Navvaro et al. 2018, p.3). In this study banking sector is chosen where intense interpersonal competition is experienced. The banking sector is one of the most competitive sectors in Turkey. This competition at the sectorial level causes pressure on employees and may lead to competition among them. The intensive use of knowledge management technologies in the banking sector is another reason to choose the sample from this sector. In literature, it is observed that there are some studies (Abbas et al., 2013; Abuazoum and Azizan 2013; Bilal, 2019; Milošević et al., 2019) on knowledge sharing in the banking sector. Knowledge is considered as an important asset and knowledge sharing among employees is considered as vital in banking sector (Kridan and Goulding 2006, p.216). Knowledge sharing provides competitive advantages to businesses. Interruption of knowledge sharing for any reason can have serious negative impacts on banks. The fact that the employees keep their unique knowledge to themselves can negatively affect the formation of new knowledge in the long term and can harm the spirit of cooperation among the employees (Dogan and Vecchio, 2015). Besides, the customers who receive services may also be affected negatively. The fact that knowledge sharing is important in the banking sector and the competition is intense enough to trigger dispositional envy in this sector leads to the selection of banking sector employees as a sample. The sample consists of 175 banking sector employees.

In this study, under the title of literature review, dispositional envy and knowledge sharing terms are described respectively and the relationship between dispositional envy and 
knowledge sharing is discussed according to the related studies. In this part it is also described how the research model and hypothesis are constructed. Under the title of methodology, the research process and the findings obtained within the scope of the study are given. In discussion and conclusion part, the research is concluded by the essential results, the findings are discussed by referring to the related studies in the literature, limitations of the study are explained and suggestions are given for future studies.

\section{LITERATURE REVIEW}

\subsection{Social Value Orientation}

Individuals experience a dilemma in social life. They make a choice whether their behavior serves for the benefit of their own or their own and others'. "Social Value Orientation" model (Lange and Liebrand, 1991) which is frequently used in the social psychology literature explains the underlying reason of individuals' preferences and suggests that individuals allocate the outputs based on their stable value orientations. These value orientations are prosocial and proself value orientations. Prosocial and proself value orientations have an impact on individuals' decisions on allocation of resources. Prosocial value orientation consists of enhancing joint outcomes while proself value orientation consists of enhancing individual interests (Lange and Liebrand, 1991; Manesi et al. 2017, Cremer and Lange, 2001; Galette et al. 2003).

Prosocials are the individuals who care of others' interests and try to increase common benefit. Compared to the proselfs, prosocials tend to be more concerned with the outcomes of others. Prosocials show willingness to help people, share their own resources as money or knowledge and act more cooperatively. They are more concerned about other individuals' wellbeing when compared with proselfs and establish closer relationships with other individuals and show empathy to them. On the other hand, proselfs are the individuals who try to maximize their own outcomes. Proselfs try to increase their self-interest rather than helping people and sharing resources. According to the literature, prosocials can abandon their collaborative attitudes towards proselfs due to the non-cooperative attitudes and behaviors of them. Prosocials can leave collaborating and defend themselves against other individuals who do not act cooperatively (Lange and Liebrand, 1991: p.276; Kleef and Lange, 2008: p.1087; Cremer and Lange, 2001). 


\subsection{Dispositional Envy}

Envy is closely associated with certain emotions as jealousy (Salovey and Rodin, 1991, Heikkinen et al., 2003). In English the nouns "envy" and "jealousy" are considered as synonymous. The difference between them is that envy arises from the desire to acquire something that another person has, while jealousy arises from the fear of losing something already owned (Vecchio, 2000; Foster, 1972).

Human nature automatically compares herself/himself to others, and as a result of this social comparison process, a sense of envy is revealed (Foster, 1972). Envy is present in every society and group; the people avoid talking about it. Envy is not an issue that is very clearly expressed and discussed in daily life. It reflects unconscious feelings (Heikkinen, et al., 2003). It emerges involuntarily and it is not easy for one person to accept it. It is almost impossible to avoid envy in social life wherever there is a human being (Foster, 1972). Envy is a negative feeling that occurs in the absence of the beautiful features as quality, success and possession that a person wishes (Parrott and Smith, 1993, p.906). According to Charash and Mueller (2007, p.666) if the things that the person lacks are very important for him/her, the person starts to envy the others who have these things. The important point is that the envious person only envies the people who he/she finds similar to him or her.

In some studies (Lange, Blatz and Crusius, 2018; Lange and Crusius, 2015, Lange, Paulhus and Crusius, 2017) envy is categorized as malicious envy and benign envy. These two concepts are related to the conclusions of envy whether what envy is. Malicious envy is about negative outcomes of envy, while benign envy is about positive outcomes of envy. Malicious envy involves hostile and unpleasant feelings towards other individuals who have superior qualities. The main feature of this concept is that it involves harming others. The individuals avoid talking about this feeling and hide it from others. On the other hand, benign envy involves positive thoughts about other individuals. The main feature of this concept is that the individuals try to improve themselves in order to be like other people whom they compare. The individuals can express their feelings openly and praise the superior person. Many researchers (Miceli and Castelfranchi, 2017; van de Ven, Zeelenberg and Pieters, 2009)) indicate that there is a resemblance between benign envy and admiration/ emulation. In some studies (Cohen- Charash and Larson, 2017; Tai, Narayanan and Mcallister, 2012) it is claimed that making a distinction by 
focusing on envy's conclusions rather than what envy is creates a meaning confusion and envy is described as a painful feeling that is obtained as a result of social comparison. In this study, this definition is supported and envy is considered as an undesired feeling resulting from an upward social comparison.

In literature, it is observed that "dispositional envy" has been studied both in the field of organizational behavior and psychology disciplines. While envy is an unpleasant feeling that reveals when the individuals realize that someone else has something that they desire, dispositional envy expresses individuals' tendencies to feel envy. Dispositional envy is a personality trait (Rentzsch and Gross, 2015b: p.530). Personality trait is a term used to describe people with stable patterns of behavior, thoughts and emotions. Since behavior, emotions and thoughts repeat consistently, they turn into a personality trait (Leduc, Feldman and Bardi, 2015: p.3). According to Xiang et al. (2017) it is the result of a "chronic feelings of inferiority and ill will”. Individuals with high dispositional envy feel a constant sense of inadequacy in themselves and generally feel that they are inferior to others. Negative social comparisons with others increase individuals' sense of inferiority (Smith, et al. 1994; Rentzsch and Gross, 2015b: p.530531). Even if every individual has a sense of envy, the tendencies to envy vary.

There are two components of dispositional envy. These are being "hostile" and "depressive” (Smith, et al., 1994). "Hostile” component stems from subjective beliefs of injustice and creates a sense of malice and anger. For instance, the fact that the person believes that he/she is being treated worse than his colleagues in the workplace can lead to tendency to envious behaviors and hostility towards the well-treated individuals. Researches (Leder et al., 2019, p.33; Fehr and Scmidt, 1999) indicate that individuals do not like inequality if they are in a disadvantaged position. According to Rentzsch et al. (2015a) individuals high in dispositional envy feel intense negative emotions when they are in a disadvantaged position relative to others. The depressive component, on the other hand, causes a feeling of inferiority resulting from the comparison of the envious prone person with other individuals who have superior qualities. The people with high dispositional envy may feel more sense of injustice and inferiority (Smith et al., 1994). Within the scope of this study, dispositional envy which is a personality trait is searched rather than the sense of envy that individuals feel as a result of social comparison in their daily experiences. 
In several studies dispositional envy is studied. In Milfont and Gouveia's (2009) study it is found that dispositional envy is negatively correlated with well-being measures which are life satisfaction, vitality and happiness. In Cohen- Charash and Mueller's (2007) study, a negative relationship is found between dispositional envy and interpersonal counterproductive work behaviors. In Smith et al.'s study (1999) dispositional envy is correlated negatively with life satisfaction and self-esteem. Also Clercq, Haq and Azeem (2018) found that dispositional envy is negatively related to job performance. The common point of these studies is that they all used Smith et al.'s (1999) dispositional envy scale to measure dispositional envy as in this study.

\subsection{Knowledge Sharing}

Davenport and Prusak (2000, p.5) states that knowledge includes values, experiences, experts and information of the professionals. The term “knowledge” is not included in the firm's documents. For this reason, Serge (1997) indicates that sharing knowledge is more than sharing information. When employees share their personal knowledge, they add their own experiences and opinions to that information for the benefit of others. This causes knowledge to turn into something valuable. According to Kridan and Goulding's (2006, p.216) study on employees working in banks which is designed through qualitative research methods, ninety-six percent of the respondents state that knowledge is the most valuable asset for the banking sector. It is observed that the participants emphasize the necessity of knowledge sharing to increase the efficiency of banks and meet international banking standards.

According to Hansen and Avital (2005, s.6), knowledge sharing is a voluntary act of giving others access to one's own knowledge and expertise. Knowledge shared person can use this information, experience etc. to generate new knowledge. Quinn (1996) states that "knowledge is one of the few assets that grow - also usually exponentially - when shared". Knowledge sharing provides competitive advantage to businesses and also it is accepted as a critical step for business achievement (Lee and Ahn, 2005, p.229; Wang and Noe, 2010, p.115). Knowledge sharing through the organization improves existing corporate business processes and provides more efficient and effective business processes (Kridan and Goulding, 2006, p.212). The company uses knowledge of its employees to advance its economic interests (Lee and Ahn, 2005, p.229). The fact that knowledge sharing among employees is interrupted for any reason affects the firm negatively. The firms must encourage their members and strategic partners to 
share knowledge. With the development of information technologies and knowledge management systems, knowledge exchange between internal and external stakeholders has been easier (Hansen and Avital, 2005).

\subsection{The Relationship between Dispositional Envy and Knowledge Sharing}

Within the scope of this study, the relationship between dispositional envy which is a personal trait and knowledge sharing is investigated. In literature, there are several studies (Wang and Noe, 2010; Gupta, 2008; Matzler et al. 2008) investigating the role of the individual's personal traits in knowledge sharing. However, there is no study found investigating the relationship between dispositional envy and knowledge sharing. In literature, it is observed that dispositional envy is searched in several studies. Although there is no study found examining the relationship between dispositional envy and knowledge sharing, there are a limited number of studies (Nandedkar and Midha, 2014; Nandedkar, 2016) investigating the relationship between envy which is a feeling and knowledge sharing. The findings of these studies (Nandedkar and Midha, 2014; Nandedkar, 2016) show that there is a negative relationship between envy and knowledge sharing. According to Gonzalez- Navvaro et al.'s (2018) study, it is found that there is a positive relationship between envy and counterproductive work behaviors as keeping vital knowledge, gossiping etc.

According to "Social Value Orientation" model, individuals make their choices according to two value orientations: proself and prosocial. Many studies suggest that dispositional envy consist of proself value orientations which make them increase their own resources, outcomes and interests rather than benefiting others (Rentzsch and Gross, 2015b: p.530; Smith et al. 1999). In Leder et al.'s (2019, p.38) research it is found that individuals with high dispositional envy often make decisions based on their personal interests when there is a conflict between selfinterest and joint welfare. Within the scope of this study, the dispositional envy is considered to include proself value orientations and the individuals with dispositional envy are considered as proselfs.

Several studies (Galetta et al., 2003: p.9; Marks et al. 2008: p.62- 63; Balau and Utz, 2017; Moser, 2017; Cyr and Choo, 2010) indicate that proselfs are reluctant to share their knowledge. According to the results of Galetta et al.'s (2003) study, proselfs don't share their 
valuable knowledge with other group members. However, when they are subjected to managerial control, they begin to share their valuable knowledge. The number of knowledge they share is limited and they don’t share as much knowledge as prosocials. Balau and Utz (2017) find similar results in their research which indicate that proselfs share less unique knowledge than prosocials. Also Cyr and Choo (2010) find that proselfs show less cooperative attitudes and share less knowledge than prosocials. Marks et al. (2008) state that proselfs are not willing to exhibit collaborative attitudes as knowledge sharing. Managerial prompts lead them to share their knowledge. According to the results of Moser's (2017) study, proself novices tend to hide their knowledge rather than sharing. The proselfs in expert status share their knowledge considering that they will increase their own outcomes from this behavior. Moser (2017) indicates that proselfs in expert positions think strategically, share their knowledge for the recognition of their expertise and therefore to increase their power in the business. As indicated above in several studies (Galetta et al., 2003: p.9; Marks et al. 2008: p.62- 63; Balau and Utz, 2017; Cyr and Choo, 2010) it is found that proselfs are reluctant to share knowledge. In this study individuals with dispositional envy are considered as proselfs and therefore this study is designed to investigate the relationship between dispositional envy and knowledge sharing based on "Social Value Orientation” model. It is hypothesized below:

$\boldsymbol{H}_{1}$ : Dispositional envy is negatively related to knowledge sharing.

\subsection{The Research Model}

The research model of this study is shown below:

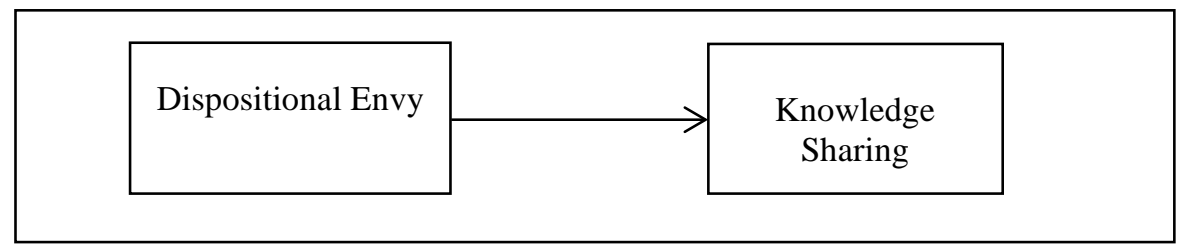

Figure 1. The Relationship between Dispositional Envy and Knowledge Sharing 


\section{METHODOLOGY}

This study is designed to investigate the relationship between dispositional envy and knowledge sharing in banking sector. Information about the data collection process, scales, analyzes and findings are given below.

\subsection{Data Collection}

The sample consists of banking sector employees in Tarsus which is a major town of Mersin. The employees were chosen by convenience sampling method. The research was applied by questionnaires. The answers of the respondents to the statements were scored and processed into SPSS 23 program. The statements were scored from five to one point Likert format (1. Completely Disagree 2. Disagree 3. Not Disagree Nor Agree 4. Agree 5. Completely Agree).

\subsection{Measures}

According to the literature, there are different dispositional envy scales. In this study Smith et al.'s (1999) dispositional envy scale was used. The scale was used widely in several studies (Milfont and Gouveia, 2009; Kim et al., 2013; Parks and Rumble, 2002) and its reliability and validity were tested in many studies (Rui, et al., 2013; Mola, et al., 2014). The scale consists of eight items such as "Feelings of envy constantly torment me". The Cronbach $\alpha$ coefficient for this scale is 0.979 in this sample.

Knowledge sharing scale was taken from Connelly et al.'s (2012) study. Knowledge sharing scale was used widely in several studies (Bavik, Tang, Shao and Lam, 2015; Connely, Ford, Turel, Gallupe and Zweig 2014; Bavik, 2015) and consists of five items such as "When my partner asked me the question, I explained everything very thoroughly". The scale shows high reliability with a Cronbach $\alpha$ coefficient for this scale of 0.899 in this sample.

The scales were used for the first time in this research in Turkey. The scales' translations to Turkish and back translations to English were done by the author of this research. The scales' translations were also reviewed by different academicians. The construct validity and reliability analyses of the scales were done. Also, frequency analysis, exploratory factor analysis and correlation analysis were done within the scope of the study. 


\subsection{Sample Characteristics}

A total of 189 employees participated in this survey. Of these, 14 surveys were eliminated because of incomplete answers. Thus, the final sample size decreased to 175. The participants filled the survey via internet. The demographic characteristics of the sample are presented in Table 1. Approximately 44 percent of the respondents are female and 56 percent are male. Most of the participants are between the ages of 21-30 and have work experience between 5-10 years. Also most of the respondents (55\%) have bachelor degree.

Table 1. Demographics

\begin{tabular}{|l|l|l|}
\hline Demographic Characteristics & f & \% \\
\hline Gender & 78 & $44 \%$ \\
Male & 97 & $56 \%$ \\
Female & & \\
Age & - & - \\
20 and below & 94 & $54 \%$ \\
$21-30$ & 71 & $40 \%$ \\
$31-40$ & 10 & $6 \%$ \\
$41-50$ & - & - \\
51 and above & & \\
Work Experience & 60 & $34 \%$ \\
$1-5$ & 74 & $42 \%$ \\
$5-10$ & 29 & $17 \%$ \\
$10-15$ & 5 & $3 \%$ \\
$15-20$ & 7 & $4 \%$ \\
20 and more & & \\
\hline Education & - & - \\
High school Degree & 12 & $7 \%$ \\
Associate Degree & 96 & $55 \%$ \\
Bachelor Degree & 60 & $34 \%$ \\
Master Degree & 7 & $4 \%$ \\
Doctorate Degree &
\end{tabular}

\subsection{Findings}

The KMO (Kaiser-Meyer-Olkin) and Bartlett's sphericity test values belonging to the dispositional envy scale are shown in Table 2. The KMO sample adequacy value (0.810) and the Bartlett Test significance level (0.000) indicate the adequacy of the sample size. 0,810 is greater than 0.60 indicating sufficient items for each factor. 
Table 2. KMO and Bartlett's Test

\begin{tabular}{|l|l|r|}
\hline \multicolumn{2}{|c|}{ Kaiser-Meyer-Olkin Measure of Sampling Adequacy. } & $\mathbf{8 1 0}$ \\
\hline \multirow{3}{*}{ Bartlett's Test of Sphericity } & Approx. Chi-Square & 315,482 \\
\cline { 2 - 3 } & df & 10 \\
\cline { 2 - 3 } & Sig. & $\mathbf{0 0 0}$ \\
\hline
\end{tabular}

Table 3 shows the results of exploratory factor analysis of dispositional envy variable. No item was removed from the dispositional envy scale. Table 3 shows the factor loads of 8 dispositional envy items ranged between 0.872 and 0.977 . The scale shows high reliability with a Cronbach $\alpha$ coefficient for this scale of 0.979 in this sample.

Table 3. Exploratory factor analysis of Dispositional Envy Scale

\begin{tabular}{|c|c|c|c|}
\hline Items & EN & $\begin{array}{l}\text { \% of } \\
\text { variance } \\
\text { explained }\end{array}$ & $\begin{array}{l}\text { Cronbach's } \\
\text { alpha }\end{array}$ \\
\hline Feelings of envy constantly torment me. & 0.977 & \multirow{8}{*}{89.748} & \multirow{8}{*}{0.979} \\
\hline It somehow doesn't seem fair that some people seem to have all the talent. & 0.967 & & \\
\hline I feel envy every day. & 0.958 & & \\
\hline No matter what I do, envy always plagues me. & 0.958 & & \\
\hline The bitter truth is that I generally feel inferior to others. & 0.956 & & \\
\hline Frankly, the success of my neighbors makes me resent it. & 0.950 & & \\
\hline I am troubled by feelings of inadequacy. & 0.938 & & \\
\hline It is so frustrating to see some people succeed so easily. & 0.872 & & \\
\hline
\end{tabular}

The KMO (Kaiser-Meyer-Olkin) and Bartlett's sphericity test values belonging to the knowledge sharing scale are showed in Table 4. The KMO sample adequacy value $(0.951>0.60)$ and the Bartlett Test significance level (0.000) indicate the adequacy of the sample size selected.

Table 4. KMO and Bartlett's Test

\begin{tabular}{|r|c|r|}
\hline \multicolumn{2}{|c|}{ Kaiser-Meyer-Olkin Measure of Sampling Adequacy. } & $\mathbf{9 5 1}$ \\
\hline \multirow{3}{*}{ Bartlett's Test of Sphericity } & Approx. Chi-Square & 1218,428 \\
\cline { 2 - 3 } & df & 28 \\
\cline { 2 - 3 } & Sig. & $\mathbf{0 0 0}$ \\
\hline
\end{tabular}

Table 5 shows the factor loads of 5 knowledge sharing items ranged between 0.705 and 0.932 as a result of the Exploratory Factor Analysis. No question was eliminated from the scale. The scale shows high reliability with a Cronbach $\alpha$ coefficient for this scale of 0.899 in this sample. 
Table 5. Exploratory Factor Analysis of Knowledge Sharing Scale

\begin{tabular}{|c|c|c|c|}
\hline Items & KS & $\begin{array}{l}\% \text { of } \\
\text { variance } \\
\text { explained }\end{array}$ & $\begin{array}{l}\text { Cronbach's } \\
\text { alpha }\end{array}$ \\
\hline $\begin{array}{l}\text { 3. When my partner asked me the question, I told my counterpart exactly what s/he } \\
\text { needed to know. }\end{array}$ & 0.932 & \multirow{4}{*}{71.614} & \multirow{4}{*}{0.899} \\
\hline $\begin{array}{l}\text { 5. When my partner asked me the question, I answered all his/her questions } \\
\text { immediately. }\end{array}$ & 0.882 & & \\
\hline $\begin{array}{l}\text { 4. When my partner asked me the question, I looked into the request to make sure } \\
\text { my answers were accurate. }\end{array}$ & 0.837 & & \\
\hline 1.When my partner asked me the question, I explained everything very thoroughly. & 0.705 & & \\
\hline
\end{tabular}

The results of correlation analysis are shown below. As seen in Table 6 below, the sample consists of $175(\mathrm{~N})$ respondents and the correlation rate between dispositional envy and knowledge sharing is $\mathrm{r}=-0.497^{* *}$. This result means that there is a significant negative relationship between dispositional envy and knowledge sharing.

Table 6. Correlation Analysis

\begin{tabular}{|l|l|l|l|}
\hline \multirow{4}{*}{ KS } & & \multicolumn{1}{|c|}{ KS } & \multicolumn{1}{|c|}{ EN } \\
\cline { 2 - 4 } & Pearson Correlation & 1 & $\mathbf{- , 4 7 9 * *}$ \\
\cline { 2 - 4 } & Sig. (2-tailed) & &, 000 \\
\cline { 2 - 4 } & $\mathrm{N}$ & 175 & 175 \\
\hline \multirow{3}{*}{ EN } & Pearson Correlation & $\mathbf{- , 4 7 9 * *}$ & 1 \\
\cline { 2 - 4 } & Sig. (2-tailed) &, 000 & \\
\cline { 2 - 4 } & $\mathrm{N}$ & 175 & 175 \\
\hline
\end{tabular}

**. Correlation is significant at the 0.01 level (2-tailed).

\section{DISCUSSION and CONCLUSION}

According to the findings of this study, a significant negative relationship is found between dispositional envy and knowledge sharing. The study was based on "Social Value Orientation" model and individuals with dispositional envy were defined as proselfs based on the studies in the literature. Many studies (Galetta et al., 2003: p.9; Marks et al. 2008: p.62- 63; Balau and Utz, 2017; Moser, 2017; Cyr and Choo, 2010) suggest that proselfs are reluctant to share knowledge. Galetta et al. (2003) indicate that proselfs don't share their valuable knowledge with other group members. Marks et al. (2008) state that proselfs are not willing to exhibit collaborative attitudes as knowledge sharing. In this study, the findings indicate a negative relationship between dispositional envy and knowledge sharing. In this context, the findings of this study coincide with the findings of other studies (Galetta et al., 2003: p.9; Marks et al. 2008: 
p.62- 63; Balau and Utz, 2017; Moser, 2017; Cyr and Choo, 2010), investigated the knowledge sharing and social value orientation.

Dispositional envy leads individuals to behave towards increasing their own interests rather than providing common benefits (Rentzsch ve Gross, 2015b: s.530; Smith et al., 1999). Individuals with high dispositional envy feel uncomfortable when their colleagues have higher qualifications than them and hide their valuable information from them. In Leder et al.'s (2019, p.38) research it is found that individuals with high dispositional envy often make decisions based on their personal interests when there is a conflict between self-interest and joint welfare. The findings obtained within the scope of this study are in line with Leder et al.'s (2019) findings. It is observed that individuals with high dispositional envy share less knowledge rather than providing a common benefit.

There are many individual barriers that prevent knowledge sharing in the literature. These barriers are obstacles arising from the individual. Factors such as lack of trust in people, low awareness, poor communication with individuals, ethnic differences, gender differences are considered as individual barriers (Riege, 2005:23-24). As a result of the findings obtained with this study, it can be questioned whether dispositional envy, which is a personality trait, can be treated as a barrier. Additional studies can be done to reveal this.

According to the literature, business environment is seen as an important factor affecting dispositional envy (Dogan and Vecchio 2015, p.58). Gonzalez- Navvaro et al. (2018, p.3) state that dispositional envy can arise in organizations where intensive interpersonal competition is intense. Within the scope of this study, this assumption has been tested and verified by selecting the banking sector where competition is intense at both sectoral and employee levels. For future studies, it is suggested to investigate the relationship between dispositional envy and knowledge sharing in a sector where competition is not intense. Thus the accuracy of this assumption will be tested again and it can be observed whether competition has an impact on this relationship.

The following recommendations are made to the managers within the scope of this study. Dispositional envy arises from the individuals' subjective beliefs of injustice. The degree of dispositional envy can increase if the individual thinks that he/she has received less reward compared to the other individual who works in a similar position (Smith, Parrot, Ozer and Moniz, 
1994). Managers should be aware of the damages of dispositional envy to the business and avoid discriminatory behaviors that can lead to high dispositional envy among employees. Kridan and Goulding (2006, s.216) state that sharing knowledge is vital for banking sector. The interruption of knowledge sharing due to employees with dispositional envy can decrease the efficiency of banks and prevent the emergence of new knowledge between employees. In this context, in sectors where knowledge technologies are used intensely such as banking sector, managers should avoid discriminatory and unfair behaviors that increase dispositional envy.

It is mentioned in several studies (Galetta et al., 2003: p.9; Marks et al. 2008) that managerial prompts or control are used to increase knowledge sharing of proselfs who are considered as individuals with dispositional envy within the scope of this study. Although proselfs are reluctant to share knowledge, they can share knowledge when there is a managerial control or prompt. For this reason, managers are recommended to benefit from managerial control or prompts when working with individuals with dispositional envy to increase knowledge sharing. 


\section{REFERENCES}

Abbas, F., Rasheed, A., Um-e-Habiba, and Shahzad, I. (2013), "Factors promoting knowledge sharing and knowledge creation in banking sector of Pakistan", Management Science Letters, 3, 405-414.

Abuazoum, A. A., Azizan, N., and Ahmad, N. (2013). Knowledge Sharing for the Islamic Banking Sector in Malaysia. International Journal of Computer and Communication Engineering, 2(3), 368-371.

Al Qeisi, K. I., and Al Zagheer, H. M. (2015). Determinants of knowledge sharing behaviour among personnel in banking industry. International Journal of Business and Management, 10(4), 49-59.

Bălău, N. and Utz, S. (2017). Information sharing as strategic behaviour: the role of information display, social motivation and time pressure, Behaviour and Information Technology, Vol. 36 No. 6, pp. 589-605.

Bavik, Y. L., Tang, P. M., Shao, R., \& Lam, L. W. (2018). Ethical leadership and employee knowledge sharing: Exploring dual-mediation paths. The Leadership Quarterly, 29(2), 322-332.

Bavik, F. (2015). Effects of goal interdependence on help-seeking through knowledge sharing and knowledge hiding : the moderating roles of reciprocity beliefs, Master's Thesis, Lingnan University, Hong Kong.

Bedeian, A. G. (1995). Workplace envy. Organizational Dynamics, 23, 49-56.

Bilal, H. (2019). Investigating the Effect of Knowledge Sharing Behavior and Job Satisfaction: Evidence from Banking Sector, City University Research Journal, 2(9), 404-414.

Charash, Y. C. and Mueller, J. S., (2007). Does Perceived Unfairness Exacerbate or Mitigate Interpersonal Counterproductive Work Behaviors Related to Envy, Journal of Applied Psychology, 92(3), 666-680.

Cohen-Charash, Y., \& Larson, E. (2017b). An emotion divided: Studying envy is better than studying “benign” and “malicious” envy. Current Directions in Psychological Science, 26, 174-183.

Connelly, C. E., Zweig, D., Webster, J., \& Trougakos, J. P. (2012). Knowledge hiding in organizations. Journal of Organizational Behavior, 33(1), 64-88.

Connelly, C.E., Ford, D.P., Turel, O., Gallupe, B. and Zweig, D. (2014), “I'm busy (and competitive)! Antecedents of knowledge sharing under pressure”, Knowledge Management Research \& Practice, Vol. 12 No. 1 , pp. 74-85.

Cyr, S. and Choo, C.W. (2010). The individual and social dynamics of knowledge sharing: An exploratory study. Journal of Documentation, 66(6), 824-846.

Davenport, T. H., and Prusak, L. (2000). Working Knowledge: How Organization Manage What They Know. Boston: Harved Business School Press. 
De Clercq, D., Haq, I.U. and Azeem, M.U. (2018), “The roles of informational unfairness climate in the relationship between dispositional envy and job performance organizations”, Journal of Business Research, Vol. 82 No. C, pp. 117-126.

Erdil, O.; Müceldili, B. The effects of envy on job engagement and turnover intention. Procedia-Social Behavioral Science 2014, 150, 447-454.

Fehr, E., and Schmidt, K. M. (1999). A theory of fairness, competition, and cooperation. The Quarterly Journal of Economics, 114(3), 817-868.

Foster, M. (1972). The Anatomy of Envy: A Study in Symbolic Behavior. In: Current Anthropology. The University of Chicago Press, Chicago, 165-186.

Gazor, H., Koohkan, F., Kiarazm, A., and Nazari Ameleh, K., (2012). Influential factors on knowledge sharing in banking industry. Management Science Letters, 2(6), 2215-2224.

González-Navarro P, Zurriaga-Llorens R, Tosin Olateju A, Llinares-Insa L. (2018). Envy and counterproductive work behavior: The moderation role of leadership in public and private organizations. Int $\mathrm{J}$ Environ Res Public Health, 15(7), 1455.

Gupta, A. K., and V. Govindarajan. 2000. “Knowledge Flows Within Multinational Corporations.” Strategic Management Journal 21: 473-496.

Hansen, S.,Avital, M. (2005). Share and share alike: The social and technological influences on knowledge sharing behavior, Working Papers on Information Systems, 1-20.

Heikkinena, E., Latvalaa, E. and Isolab, A., (2003). Envy in a nurse education community, International Journal of Nursing Studies, 40, 259-268.

Kim, S.K., Jung, D.I. and Lee, J.S. (2013), “Service employees’ deviant behaviors and leadermember exchange in contexts of dispositional envy and dispositional jealousy”, Service Business, Vol. 7 No. 4, pp. 583-602.

Kridan, A. B. and Goulding J. S. (2006). A case study on knowledge management implementation in the banking sector, The Journal of Information and Knowledge Management Systems, 36, 2, 211-222.

Lange, J., Blatz, L., \& Crusius, J. (2018). Dispositional envy: A conceptual review. In V. Zeigler-Hill \& T. K. Shackelford (Eds.), SAGE Handbook of personality and individual differences.

Lange, J., and Crusius, J. (2015). Dispositional envy revisited: Unraveling the motivational dynamics of benign and malicious envy. Personality and Social Psychology Bulletin, 41, 284-294.

Lange, J., Paulhus, D. L., \& Crusius, J. (2018). Elucidating the dark side of envy: Distinctive links of benign and malicious envy with dark personalities. Personality and Social Psychology Bulletin.

Lee, D. J., Ahn, J. H. (2005). Rewarding knowledge sharing under measurement inaccuracy, Knowledge Management Research and Practice, 3, 229-243. 
Leder, J., Bartowiak P., Niedermanner, Schütz, A., Rentzsch, K. (2020). Self - interest or joint welfare? Person and situation factors in interpersonal decisions about time, Journal of Theoretical Social Psychology, 4(1), 32- 42.

Matzler, K., Renzl, B., Muller, J., Herting, S. and Mooradian, T.A. 2008. Personality Traits and Knowledge Sharing. Journal of Economic Psychology, 29: 301-313.

Marks, P., Polak P., McCoy S., Galetta D. (2008). Sharing Knowledge, Communications of the ACM, 51(2), 60-65.

Miceli, M., \& Castelfranchi, C. (2007). The envious mind. Cognition \& Emotion, 21, 449-479.

Milfont, T. L., and Gouveia, V. V. (2009). A capital sin: dispositional envy and its relations to wellbeing. Interamerican Journal of Psychology, 43(3), 547-551.

Milošević, N., Tošković O., Barjaktarović Rakočević S. (2019). Does Perceived Top Management Involvemet and Knowledge Sharing Affect Perceived Project Performance? Evidence from the Banking Sector, Journal of East European Management Studies, 2, 259- 279.

Moser, K. S. (2017). The influence of feedback and expert status in knowledge sharingmg dilemmas. Applied Psychology: An International Review, 66(4), 674- 709.

Nandedkar, A. (2016), "Investigating leader-member exchange and employee envy: An evidence from the information technology industry", International Journal of Organization Theory and Behavior, Vol. 19 No. 4, 419451.

Nandedkar, A. Midha, V. (2014). An International Perspective Concerning Impact of Supervisor Subordinate Relationship on Envy, Knowledge Sharing, and Relational Conflict among Employees", Journal of International and Interdisciplinary Business Research, 1, 89-104.

Parks, C. D., Rumble, A. C., and Posey, D. C. (2002). The effects of envy on reciprocation in a social dilemma. Personality and Social Psychology Bulletin, 28, 509-520.

Parrott, W. G., and Smith, R. H. (1993). Distinguishing the experiences of envy and jealousy. Journal of Personality and Social Psychology, 64, 906-920.

Parks-Leduc, L., Feldman, G., \& Bardi, A. (2015). Personality traits and personal values: A meta-analysis. Personality and Social Psychology Review, 19(1), 3- 29.

Rentzsch, K., Schröder-Abé, M., and Schütz, A. (2015a). Envy mediates the relation between low academic self-esteem and hostile tendencies. Journal of Research in Personality, 58, 143-153.

Rentzsch, K. and Gross, J. J. (2015b). Who turns green with envy? Conceptual and empirical perspectives on dispositional envy: Dispositional envy. European Journal of Personality, 29, 530-547. 
Salovey, P., and Rodin, J. (1991). Provoking jealousy and envy: Domain relevance and self-esteem threat. Journal of Social and Clinical Psychology, 10, 395-413.

Senge, P. (1997). Sharing Knowledge. Executive Excellence. 15, 11-12.

Smith, R. H., Turner, T. J., Garonzik, R., Leach, C. W., Urch-Druskat, V., Weston, C. M. (1996). Envy and Schadenfreude, Personality and Social Psychology Bulletin, 22, 158 -168.

Tai, K., Narayanan, J. and McAllister, D.J. (2012). Envy As Pain: Rethinking the Nature of Envy and Its Implications for Employees and Organizations. The Academy of Management Review, 37, 107-129.

Tholath, D.I. and Thattil, G.S. (2016). Motivational Drivers of Knowledge Sharing in the Banking Sector of India. IUP Journal of Knowledge Management, 14(1), 33-44.

Quinn, J.B. (1996), “Leveraging intellect”, Academy of Management Executive, 10(3), 7-27.

van de Ven, N., Zeelenberg, M., \& Pieters, R. 2009. Leveling up and down: The experiences of benign and malicious envy. Emotion, 9: 419-429.

Vecchio, R. P. 2000. Negative emotion in the workplace: Employee jealousy and envy. International Journal of Stress Management, 7(3): 161-179.

Veiga, J. F., Baldridge, D. C., and Markóczy, L. (2014). Toward greater understanding of the pernicious effects of workplace envy. International Journal of Human Resource Management, 25, 2364-2381.

Wang, S. and Noe, R. (2010). Knowledge Sharing: A Review and Directions for Future Research, Human Resources Management Review, 20, 115- 131.

Xiang, Y., Zhao, S., Wang, H., Wu, Q., Kong, F., \& Mo, L. (2017). Examining brain structures associated with dispositional envy and themediation role of emotional intelligence. Scientific Reports, 7, 39947. 